\title{
Effect of Magnetic Therapy on Clinical and Laboratory Parameters for the Patients Who have Undergone Pneumonia Caused by the New Coronavirus Infection
}

\section{RA Bodrova ${ }^{1,2 *}$, AD Zakamyrdina'2 ${ }^{2}$ IA Fakhrutdinov ${ }^{2}$, AM Delyan ${ }^{3}$, RR Mavzyutova $^{2}$ and ER Yunusova ${ }^{1,3}$}

${ }^{1}$ Kazan State Medical Academy - A Branch of the Federal State, Budgetary Education Institution of Higher Professional Education, Russian Medical Academy of Continuing Vocational Education of the Ministry of Healthcare of the Russian Federation, Russia ${ }^{2}$ State Autonomous Healthcare Institution Hospital for War Veterans of Kazan, Russia ${ }^{3}$ State Autonomous Healthcare Institution City Clinical Hospital No. 7 of Kazan, Russia *Corresponding Author: RA Bodrova, Kazan State Medical Academy - A Branch of the Federal State, Budgetary Education Institution of Higher Professional Education, Russian Medical Academy of Continuing Vocational Education of the Ministry of Healthcare of the Russian Federation, Russia.
Received: August 12, 2021

Published: September 06, 2021

(C) All rights are reserved by RA Bodrova., et al.

\section{Abstract}

The article is devoted to a comprehensive prospective clinical study of effectiveness of use of low-frequency magnetic therapy in medical rehabilitation of the patients with viral pneumonia in the convalescence phase by comparing it with a group of patients not receiving magnetic therapy in the rehabilitation program. The aim of this work is to study the effect of low-frequency magnetic therapy on improving the function of external respiration, on increasing the efficiency and shortening the rehabilitation period for patients with viral pneumonia in the phase of convalescence. The study included 200 patients (mean age $54.5 \pm 5.2$ years) who had experienced pneumonia caused by COVID-19. Group I (Main Group) consisted of 100 patients who received low-frequency magnetic therapy daily for 20 minutes on the background of a standard therapy beginning from 16-21 days after discharge from the hospital, a course of 15 procedures. Group II (Control Group) consisted of 100 patients who received low-frequency placebo magnetic therapy daily for 20 minutes beginning from the $16^{\text {th }}$ to $21^{\text {st }}$ days after discharge from the hospital, a course of 15 procedures.

To determine the dynamic clinical and laboratory parameters and effectiveness of therapy in this study in accordance with the Temporary Clinical Recommendations of the Ministry of Health of Russia, the following were used: physical examination, pulse oximetry, rating scales: dyspnea scale mMRC (Modified Medical Research Council); Borg dyspnea scale, quality of life questionnaire (EQ-5D), and CBC [9].

Results and Discussion: Patients of Group I (Main Group) had a decrease in leukocytosis by 30.3\% in the general blood analysis. $43 \%$ (43 people) of the patients of Group I (Main Group) demonstrated an improvement in the parameters with auscultation of the lungs, with spirometry, an increase in the vital capacity of the lungs by $28.2 \%(p=0.0021)$. When assessing the function of the respiratory muscles, there was an increase in chest excursion in Group I (Main Group) by 53.1\% ( $p=0.0019$ ). Also, patients of Group I (Main Group), demonstrated a decrease in the degree of dyspnea according to the mMRC scales by 50\% and Borg by 33.3\% (p = 0.0016), there was a significant increase in the quality of life according to the EQ-5D questionnaire by 23\% ( $p=0.0019)$. Also, a decrease in duration of staying on sick leave by $3.4 \pm 0.2$ days was observed in Group I (Main Group).

Conclusion: Application of low-frequency magnetic therapy in the complex rehabilitation of patients, who have had pneumonia caused by the new coronavirus infection, improves the function of external respiration of the patients, which is confirmed by a sub- 
jective assessment of the patients, physical examination, spirometry data, and a decrease in shortness of breath on the Borg scale and mMRC. A decrease in duration of the rehabilitation period and terms of incapacity for work has been revealed; improvement of the general well-being of patients, their emotional state, which contributed to restoration of in everyday activity and an increase in the quality of life of the patients.

Keywords: Low-frequency Magnetic Therapy; Medical Rehabilitation; Pneumonia; New Coronavirus Infection; COVID-19

\section{Introduction}

To date, attention of the entire world community is focused on one common problem - spreading of the new coronavirus infection (COVID-19). The first reports of cases of the new coronavirus infection appeared in the city of Wuhan, Hubei province (People's Republic of China) at the end of December 2019 [1,2]. The infection rapidly spread throughout China, and the World Health Organization (WHO; World Health Organization, WHO) recognized an outbreak of infection a month later, and a pandemic was declared on March 11, 2020 [3].

At the end of May 2021, a series of medical images appeared on the site, on which you can see many X-ray manifestations of the new coronavirus infection (SARS-CoV-2 infection), including images obtained with computed tomography (CT) , X-rays, images, obtained with ultrasound examinations, echocardiography and magnetic resonance imaging (MRI). These images demonstrate examples of typical COVID pneumonia and numerous complications that the virus causes in the body in many organs, including brain, kidneys, heart, abdomen, and vascular system [11]. In addition to acute manifestations of the new coronavirus infection, some patients may have persistent long-term clinical manifestations [12].

Individuals with concomitant pathology deserve special attention $[7,8]$. Most common, COVID-19 patients have: arterial hypertension (13-17\%), diabetes mellitus (5-35\%), cardiovascular diseases (3-4\%), less common: chronic lung diseases (2\%) and oncological pathology $(0,5-3 \%)[2,4-6]$. Most doctors have not previously dealt with the coronavirus infection, which requires developing optimal tactics for organizational, preventive, therapeutic and rehabilitation measures in the process of active work.

\section{Purpose of the study}

To evaluate effectiveness of use of the magnetic therapy in the complex medical rehabilitation of patients who have had pneumo- nia caused by the new coronavirus infection.

\section{Material and Methods}

200 patients with community-acquired pneumonia caused by the new viral infection COVID-19, DN 0-1, (J 16.8) were observed from June 5, 2020, at the bases of the State Autonomous Healthcare Institution (SAHI) "Hospital for War Veterans" in Kazan, SAHI "Hospital for War Veterans in Naberezhnye Chelny", SAHI "City Clinical Hospital No. 7 of Kazan" in the re-profiled departments of medical rehabilitation, in the form of a day hospital for patients after pneumonia caused by the new coronavirus infection. Asthenic condition after suffering the new viral infection COVID-19 (G 93.3) in the convalescence phase at the stage of rehabilitation. The patients were included in the study with a double negative PCR test for SARS CoV-2.

The following study design was developed: a double placebocontrolled method [10].

The average age of the patients was $54.5 \pm 5.2$ years. All patients had a stable somatic status according to the Rehabilitation Routing Scale (RRS) - the average score was $2.9 \pm+0.7$ points.

Patients of both groups (Group I (Main Group) and Group II (Control Group)) were comparable in age and sex, clinical manifestations of residual phenomena of the new coronavirus infection. There was found prevalence of women among patients $(\mathrm{p}<0.01)$ : they were $65.0 \%$ of women and $35.0 \%$ of men admitted to rehabilitation on $16.4 \pm 6.2$ days after discharge from the inpatient department of the hospital specialized in treatment of pneumonia caused by the new coronavirus infection.

The following "exclusion criteria" were established for the study: lack of the rehabilitation potential; 4 and 5 points according to the RRS, according to the test with 6-minute walk $150-300 \mathrm{~m}$, 
exercise test (bicycle ergometry/spiroergometry) 25-50 W/2-3.9 IU; angina pectoris, which occurs when walking from 100 to 500 $\mathrm{m}$ on flat terrain, when climbing one flight of standard steps, at an average pace and under normal conditions; the need for outside help when performing everyday tasks (dressing, undressing, going to the toilet, eating, etc.); instability of the somatic and neurological status; severe intoxication, hyperthermic syndrome (body temperature above $37.0^{\circ} \mathrm{C}$ ); oxygen saturation in the blood (Sp02) $<$ less than 95; \%; II-III stage of cardiopulmonary failure, chronic kidney disease and liver failure above stage II; severe rhythm and conduction disturbances (multiple group and polytopic ventricular extrasystoles, complete AV blockade, tachysystolic form of atrial fibrillation), blood diseases; hemorrhagic syndrome, pulmonary hemorrhage and presence of blood in sputum; pneumothorax, suspicion or presence of neoplasms in the affected area; presence of a pacemaker and foreign metal bodies; psychoorganic syndrome; convulsive syndrome [10].

The patients were randomized into two equal groups. Patients of Group I (Main Group = 100 people), starting from the 2nd day of staying in the day hospital, were treated with low-frequency magnetic therapy with induction - $20 \mathrm{mT}$, pulse frequency - 100 $\mathrm{Hz}$, type of magnetic field: running from right to left. During the procedures, the main emitter was placed in the posterior surface of the patient's chest. The procedures were carried out once a day for 20 minutes, 15 sessions of the therapy.

Patients of Group II (Control Group = 100 people), starting from the 2nd day of staying in the day hospital, were treated with an imitation of the magnetic therapy procedures with the main emitter of the placebo apparatus, which had appearance identical to the apparatus, but did not generate the magnetic field when it was turned on. During the procedures, the placebo emitter was also placed in the posterior surface of the patient's chest; placebo procedures were performed once a day for 20 minutes, during a course of 15 procedures.

In addition to the magnetic therapy or placebo treatment, patients of Group I (Main Group) and Group II (Control Group) received a standard therapy: a set of breathing exercises, chest massage, aerosol therapy/ozone therapy, and psychologist sessions [9].

At the end of the course of magnetic therapy procedures for patients of Group I (Main Group) and placebo procedures for patients of Group II (Control Group), a control examination of the patients was carried out in order to assess the dynamics of the clinical data, somatic status, the need for drug therapy, as well as with the purpose of assessing of presence/absence of any adverse effects of the device after the magnetic therapy treatment, according to the Interim Clinical Recommendations of the Ministry of Health of Russia "Medical rehabilitation for the new coronavirus infection (COVID-19)" (version 2.0 of July 31, 2020) [9].

After completion of the course of treatment, all patients were diagnosed with rehabilitation, control spirometry and pulse oximetry were performed, and dyspnea was assessed using the mMRC scale and the Borg scale, for an objective assessment of the dynamics of respiratory function and severity of respiratory failure. Also, a clinical blood test was performed, if required (if there were initial deviations from the norm at the time of inclusion in the study).

After 3-4 weeks and 13-14 weeks after the end of the course of procedures, all patients were also examined to assess the dynamics of clinical data based on the results of the postponed observation after the course of treatment. At these stages, the patients were interviewed to assess the dynamics of complaints, a physical examination to assess the dynamics of the somatic status. The control spirometry and pulse oximetry, assessed on the mMRC scale and the Borg scale, were performed for an objective assessment of the dynamics of respiratory function and severity of the respiratory failure. The EQ-5D questionnaire was used to assess dynamics of the patients' quality of life. A clinical blood test has been performed, if required (in the presence of initial deviations from the norm according to the results of the previous examination).

All patients who, at the time of inclusion in the study, had any residual changes in lungs according to the X-ray examination, underwent a lung control X-ray computed tomography. The timing of the X-ray control was determined by the regulatory standards of radiation safety (Sanitary Rules and Regulations 2.6.1.2523-09 Radiation Safety Standards (NRB-99/2009).

After completion of the examination of all patients included in the study, changes in the clinical data revealed in the study were identified. A comparison was made by the method of statistical analysis of the data obtained, using the GraphPadPrism7 program. In order to determine a statistical significance of differences be- 
tween Group I (Main Group) and Group II (Control Group) before and after treatment, the nonparametric Wilcoxon $\mathrm{W}$ test was used for the dependent variables [10].

\section{Results}

According to the results of the analysis of the primary data, at the time of completion of treatment in inpatient departments of hospitals that specialize in treatment of pneumonia caused by the new coronavirus infection, no pathological changes in the lungs were found in patients of Group I (Main Group), according to X-ray computed tomography (CT-0). The remaining 96 (96.0\%) of Group I (Main Group) had minor abnormalities in the form of residual changes of various severity (linear reticular thickenings, single foci of consolidation and fibrosis) after suffering from COVID pneumonia.

At the time of completion of treatment in inpatient departments of hospitals before including in the study, in Group II (Control Group): 4 (4.0\%) patients had no pathological changes in the lungs according to X-ray computed tomography; in 96 (96.0\%) patients, residual changes were also observed after suffering COVID pneumonia of varying severity.

When assessing the indicators of the general blood test in patients of Group I (Main Group), hemoglobin was $130 \pm 0.6 \mathrm{~g} / \mathrm{l}$, platelets $-290 \pm 0.3 \times 10^{9} / \mathrm{l}$, oxygen saturation in the blood was 97.0 $\pm 0.2 \%$; in Group II (Control Group), hemoglobin was $132 \pm 0.5 \mathrm{~g} / \mathrm{l}$, platelets - $286 \pm 0.4 \mathrm{x}^{109} / \mathrm{l}$, oxygen saturation in the blood was 96.8 $\pm 0.3 \%$.

At the moment of starting the therapy, 92 patients (92.0\%) of Group I (Main Group) complained of high weakness, dry cough, poor endurance; 25 patients $(25.0 \%)$ - noted irritability and poor sleep quality. In Group II (Control Group), 96 patients (96.0\%) complained of high weakness, dry cough, poor endurance; 19 patients (19.0\%) - mentioned irritability and poor sleep quality.

When making lungs auscultation at the first visit, vesicular respiration was found in $48 \%$ of patients (48 persons) of Group I (Main Group), and weakened vesicular respiration in 52\% (52 persons). In Group II (Control Group), vesicular respiration was observed in $49 \%$ (49 patients), and poor vesicular respiration was observed in 51\% (51 patients), respectively.
When making spirometry in patients of Group I (Main Group), a decrease in vital capacity of lungs was revealed in 89\% (89 persons), in Group II (Control group) - in 90\% (90 persons).

When examining a chest excursion in patients of Group I (Main Group), there was a decrease in the mobility of the lower edge of the lungs to $2.46 \pm 0.2 \mathrm{~cm}$ in $84 \%$ (84 persons) of patients; in Group II (Control Group) up to $2.76 .5 \pm 0.4 \mathrm{~cm}$ in $76 \%$ (76 persons), respectively.

According to mMRC, the majority of patients of Group I (Main Group), $84.0 \%$ (85 persons), had dyspnea of moderate severity, mild in 15\% (15 persons); in Group II (Control Group) in 83\% (83 persons), mild in 17\% (17 persons). In Group I (Main Group) on the Borg scale, moderate manifestations of shortness of breath were revealed in $90 \%$ (90 persons), mild - 10\% (10 persons), in Group II (Control Group), moderate shortness of breath 87\% (87 persons), light - 13\% (13 persons).

In Group I (Main Group), a decrease in the quality of life according to the EQ-5D questionnaire was found in 89\% (89 persons), in Group II (Control Group), in 90\% (90 persons).

After the end of the course of treatment, 84\% of patients (84 persons) of Group I (Main Group) demonstrated a decrease in weakness, in $76 \%$ (76 persons) - Decrease in intensity of shortness of breath, $82.0 \%$ (82 persons) - Decrease in intensity of cough, $78.0 \%$ (78 persons) - Improved sleep ( $p=0.0016)$. In Group II (Control Group), a decrease in weakness in $76.0 \%$ of patients (76 persons), shortness of breath in $64.0 \%$ (64 persons) of patients, cough in $79.0 \%$ (79 persons) of patients, improved sleep - in $71 \%$ (71 persons) of patients $(p=0.34)$, respectively.

In the general blood analysis of patients of Group I (Main Group), there was a decrease in leukocytosis by $30.3 \%$ (the level of leukocytes before treatment $-9.3 \pm 0.7 \times 10^{9} / \mathrm{L}$; after treatment $-6.48 \pm$ $0.3 \times 10^{9} / \mathrm{l}$ ) (Figure 1), a decrease in the erythrocyte sedimentation rate (ESR) by $36 \%$ (before treatment $-30.3 \pm 3.8 \mathrm{~mm} / \mathrm{h}$; after treatment - $19.4 \pm 1.6 \mathrm{~mm} / \mathrm{h}$ ) (Figure 2).

In Group II (Control Group), a decrease in leukocytosis was revealed by $16.5 \%$ (the level of leukocytes before treatment was 9.1 $\pm 0.9 \times 10^{9} / \mathrm{l}$; after treatment $-7.6 \pm 1.5 \times 10^{9} / \mathrm{l}, \mathrm{p}=0.16$ ) (Figure 1), decrease in ESR by $21.3 \%$ (before treatment $-30.6 \pm 3.9 \mathrm{~mm} / \mathrm{h}$; after treatment - $24.1 \pm 6.7 \mathrm{~mm} / \mathrm{h}$ ) (Figure 2). 


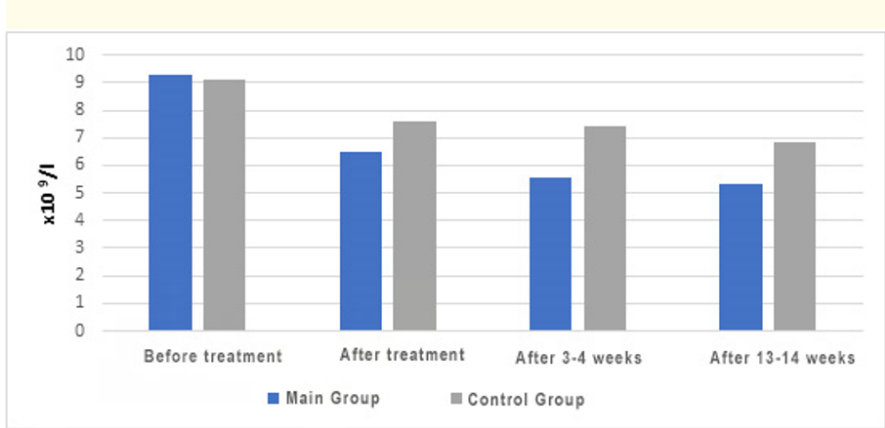

Figure 1: Parameters of ESR in patients with viral pneumonia in the phase of convalescence before and after the treatment $(\times 109 / \mathrm{l} ; \mathrm{M} \pm \sigma)$.

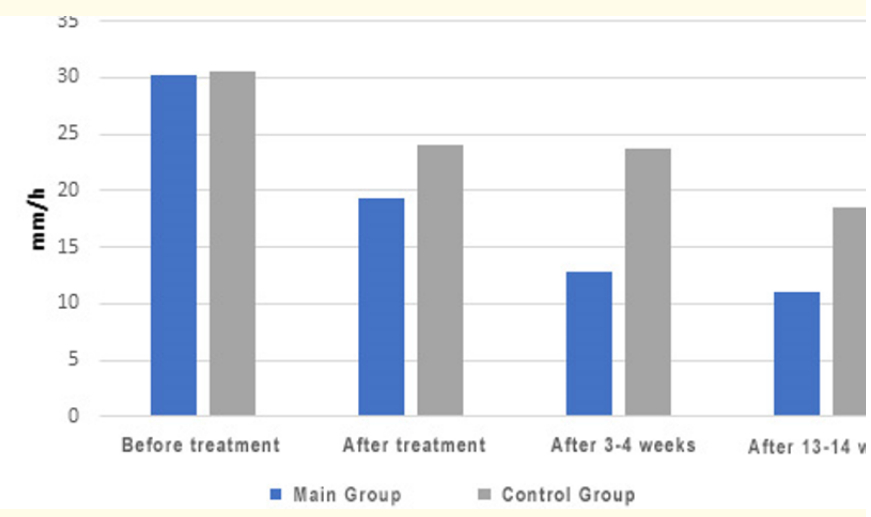

Figure 2: Dynamics of ESR in patients with viral pneumonia in the phase of convalescence before and after the treatment ( $\mathrm{mm} /$ hour;

$$
\mathrm{M} \pm \sigma) \text {. }
$$

Oxygen saturation in the blood in all patients of Group I (Main Group) (before treatment - $97.0 \pm 0.2 \%$; after treatment - $97.9 \pm$ $0.1 \%$ ) and Group II (Control Group) (before treatment - $96.8 \pm$ $0.3 \%$; after treatment $-98.1 \pm 0.1 \%$ ) remained within normal limits (Figure 3).

In patients of Group I (Main Group), a decrease in CRP was revealed (before treatment: $6.24 \pm 0.3 \mathrm{mg} / \mathrm{L}$; after treatment: $3.73 \pm$ $0.6 \mathrm{mg} / \mathrm{L}, \mathrm{p}=0.018$ ). In Group II (Control Group) - a decrease in CRP by $26.8 \%$ (before treatment: $5.4 \pm 1.6 \mathrm{mg} / \mathrm{L}$; after treatment: $3.95 \pm 0.9 \mathrm{mg} / \mathrm{L}, \mathrm{p}=0.12$ ), (Figure 4).

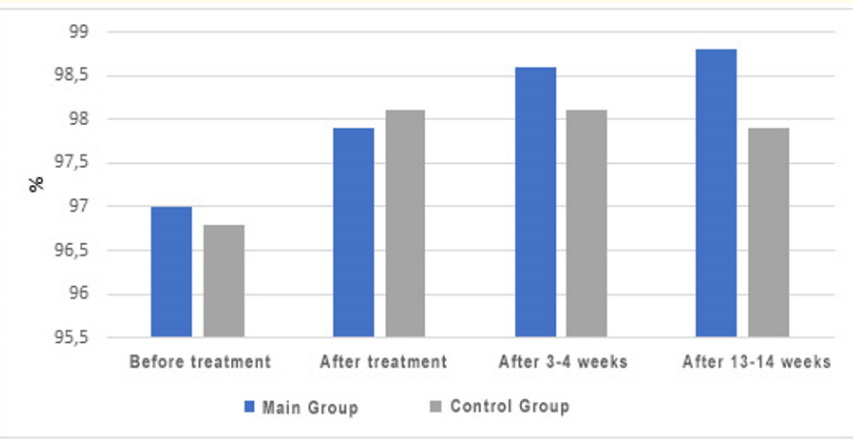

Figure 3: Parameters of oxygen saturation in patients with viral pneumonia in the phase of convalescence before and after the treatment $(\% ; M \pm \sigma)$.

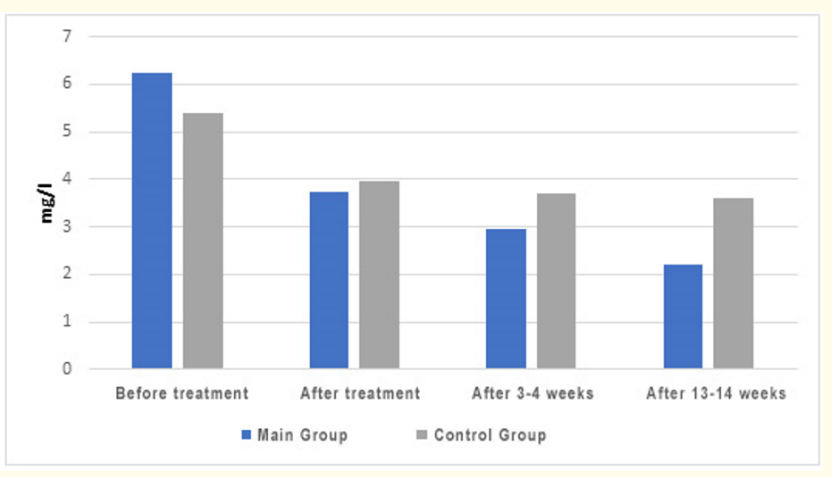

Figure 4: Parameters of ESR in patients with viral pneumonia in the convalescence phase before and after treatment (mg/l).

At auscultation of the lungs, an improvement in breathing was revealed in 43\% (43 patients) of the patients of the Main Group. In Group II (Control Group), 22\% (22 persons), respectively.

When carrying out spirometry in patients of Group I (Main Group), an increase in the vital capacity of lungs by $28.2 \%$ was found (before treatment $-2130.2 \pm 150.7 \mathrm{~cm} 3$; after treatment $2731.3 \pm 144.1 \mathrm{~cm} 3 ; \mathrm{p}=0.0021$ ); in patients of Group II (Control Group) - by $18.2 \%$ (before treatment - $2254.5 \mathrm{~cm} 3 \pm 132.7$ l; after treatment - $2664.9 \pm 149.2 \mathrm{~cm} 3 ; \mathrm{p}=0.29$ ).

There was an increase in chest excursion in Group I (Main Group) by $53.1 \%(2.45 \pm 0.2 \mathrm{~cm}$ before the treatment; $3.75 \pm 0.2$ 
Effect of Magnetic Therapy on Clinical and Laboratory Parameters for the Patients Who have Undergone Pneumonia Caused by the New Coronavirus Infection

$\mathrm{cm}, \mathrm{p}=0.0019$ after the treatment); In Group II (Control Group) by $23.6 \%$ (mobility of the lower pulmonary edge before treatment: $2.75 \pm 0.4 \mathrm{~cm}$; after treatment: $3.4 \pm 0.7 \mathrm{~cm}, \mathrm{p}=0.24$ ).

Also, the patients of Group I (Main Group) demonstrated a decrease in the degree of dyspnea on the mMRC scales by $50 \%$ (before treatment - $2.1 \pm 0.3$ points; after treatment $-1.2 \pm 0.4$ points (Table 1) and Borg by $33.3 \%$ (before treatment $-3.2 \pm 0.4$ points; after treatment $-2.4 \pm 0.3$ points, $\mathrm{p}=0.016$ (Table 2)).

\begin{tabular}{|c|c|c|c|c|}
\hline & $\begin{array}{c}\text { Before } \\
\text { treatment }\end{array}$ & $\begin{array}{c}\text { After } \\
\text { treatment }\end{array}$ & $\begin{array}{c}\text { After 3-4 } \\
\text { weeks }\end{array}$ & $\begin{array}{c}\text { After 13-14 } \\
\text { weeks }\end{array}$ \\
\hline $\begin{array}{c}\text { Main } \\
\text { group }\end{array}$ & $2.1 \pm 0.3$ & $1.2 \pm 0.4$ & $0.2 \pm 0.3$ & $0.1 \pm 0.3$ \\
\hline $\begin{array}{c}\text { Control } \\
\text { group }\end{array}$ & $1.98 \pm 0.4$ & $1.18 \pm 0.3$ & $0.58 \pm 0.3$ & $0.58 \pm 0.4$ \\
\hline
\end{tabular}

Table 1: Parameters of severity of dyspnea by the mMRC scale in patients with viral pneumonia in the phase of convalescence before and after treatment (points, $\mathrm{M} \pm \sigma$ ).

\begin{tabular}{|c|c|c|c|c|}
\hline & $\begin{array}{c}\text { Before } \\
\text { treatment }\end{array}$ & $\begin{array}{c}\text { After } \\
\text { treatment }\end{array}$ & $\begin{array}{c}\text { After 3-4 } \\
\text { weeks }\end{array}$ & $\begin{array}{c}\text { After 13-14 } \\
\text { weeks }\end{array}$ \\
\hline $\begin{array}{c}\text { Main } \\
\text { group }\end{array}$ & 3.2 & 2.4 & 0.45 & 0.45 \\
\hline $\begin{array}{c}\text { Control } \\
\text { group }\end{array}$ & 3 & 2.1 & 1 & 0.9 \\
\hline
\end{tabular}

Table 2: Parameters of severity of dyspnea by the Borg scale in patients with viral pneumonia in the phase of convalescence before and after treatment (points, $\mathrm{M} \pm \sigma$ ).

Patients of Group I (Main Group) with viral pneumonia in the convalescence phase had a significant increase in the quality of life, improvements in general mobility (mobility), household activity, a decrease in pain/discomfort, anxiety and depression were observed, while patients of Group II (Control Group) demonstrated not statistically significant changes in the placebo-magnetic therapy group; in particular, an improvement in the quality of life according to the EQ-5D questionnaire by $23 \%$ (before treatment - $11.3 \pm 1.3$ points; after treatment $-8.7 \pm 0.2$ points, $p=0.0019$ ).

In Group II (Control Group) of patients with viral pneumonia in the phase of convalescence, there was also an improvement in the quality of life according to the EQ-5D questionnaire by $3.6 \%$ (before treatment - $11.2 \pm 2.4$ points; after treatment - $11.8 \pm 2.2$ ). However, the improvements were not statistically significant $(\mathrm{p}=$ 0.62); assessment of the degree of dyspnea on the mMRC and Borg scales also demonstrated no significant improvement $(\mathrm{p}=0.125$ and $\mathrm{p}=0.54$, respectively (Tables 1,2$)$ ).

The above-described positive dynamics of the state of patients in Group I (Main Group) contributed to a decrease in the period of their disability, in particular, the sick leave was finished on the18.5th \pm 1.3 days, and in Group II (Control Group) on the $21^{\text {st }}$ \pm 1.4 days.

3-4 weeks after the complex medical rehabilitation with use of the low-frequency magnetic therapy in Group I (Main Group), the control study revealed a decrease of leukocytosis by $40.1 \%$ (before treatment - $9.3 \pm 0.7 \times 10^{9} / \mathrm{l}$; after treatment $-5,57 \pm 0.2 \times 10^{9} / \mathrm{l}, \mathrm{p}=$ 0.0034 ) (Figure 1), decrease of the erythrocyte sedimentation rate (ESR) by $57.7 \%$ (before treatment $-30.3 \pm 3.8 \mathrm{~mm} / \mathrm{h}$; after treatment $-12,8 \pm 0.6 \mathrm{~mm} / \mathrm{h}, \mathrm{p}=0.0028$ ) (Figure 2), decrease in CRP by $52.4 \%$ (before treatment $-6.24 \pm 0.3 \mathrm{mg} / \mathrm{l}$; after treatment -2.97 $\pm 0.6 \mathrm{mg} / \mathrm{l}, \mathrm{p}=0.0029$, Figure 4)). In Group II (Control Group), the final study demonstrated an insignificant increase in indicators: a decrease in the number of leukocytes by $18.6 \%$ (before treatment $-9.1 \pm 0.9 \times 10^{9} / \mathrm{l}$; after treatment $-7.4 \pm 0.6 \times 10^{9} / \mathrm{l}$, reduction CRP by $31.4 \%$ (before treatment $-5.4 \pm 1.7 \mathrm{mg} / \mathrm{l}$; after treatment $-3.7 \pm$ $1.4 \mathrm{mg} / \mathrm{l}, \mathrm{p}=0.19$ ).

13-14 weeks after the complex medical rehabilitation completed, further positive dynamics of clinical data was demonstrated, more expressed in Group I (Main Group), in which the complex of rehabilitation measures included the low-frequency magnetic therapy.

In the Group I (Main Group), the final study of the general blood test demonstrated a decrease in leukocytosis by $43.0 \%$ (before treatment - $9.3 \pm 0.7 \times 10^{9} / \mathrm{l}$; after treatment $-5.3 \pm 0.2 \times 10^{9} / \mathrm{L}, \mathrm{p}=$ 0.0034 ), a decrease in the erythrocyte sedimentation rate (ESR) by $63.7 \%$ (before treatment $-30.3 \pm 3.8 \mathrm{~mm} / \mathrm{h}$; after treatment -11.0 $\pm 0.4 \mathrm{~mm} / \mathrm{h}, \mathrm{p}=0.0028$ ), decrease in CRP by $55 \%$ (before treatment $-6.24 \pm 0.3 \mathrm{mg} / \mathrm{L}$; after treatment $-2.2 \pm 0.6 \mathrm{mg} / \mathrm{L}, \mathrm{p}=0.002$, (Figure 4)). 
In Group II (Control Group), the final study demonstrated an insignificant increase in indicators: a decrease in the number of leukocytes by $24.8 \%$ (before treatment $-9.1 \pm 0.9 \times 10^{9} / \mathrm{l}$; after treatment $-6.84 \pm 0.2 \times 10^{9} / \mathrm{l} p=0.28$ ), (Figure 1 ), ESR by $39.5 \%$ (before treatment $-30.6 \pm 4.9 \mathrm{~mm} / \mathrm{h}$; after treatment $-18.5 \pm 1.2$ $\mathrm{mm} / \mathrm{h}, \mathrm{p}=0.46$ ), (Figure 2). Reduction of CRP by $27.0 \%$ (before treatment $-5.4 \pm 1.7 \mathrm{mg} / \mathrm{L}$; after treatment $-3.94 \pm 0.3 \mathrm{mg} / \mathrm{L}, \mathrm{p}=$ 0.19 (Figure 4)).

Oxygen saturation in the blood during the final study in all patients of Group I (Main) (before treatment - $97.0 \pm 0.2 \%$; after treatment $-98.8 \pm 0.1 \%, p=0.002$ ) and Group II (Control) (before treatment $-96.8 \pm 0.3 \%$; after treatment $-97.9 \pm 0.05 \%, p=0.01$ ) remained within normal limits (Figure 3).

Vesicular breathing was kept at control examination with lung auscultation in 100\% (100 patients) of patients in Group I (Main) (Figure 3). In Group II (Control), 7\% (7 persons) retained a weakening of vesicular respiration.

When conducting spirometry, the patients had an increase by $39.9 \%$ in the vital lung capacity (VLC) $\left(2130 \pm 150.7 \mathrm{~cm}^{3}\right.$ before treatment; $2978 \pm 165.8 \mathrm{~cm}^{3} ; \mathrm{p}=0.0027$ after treatment).

The patients of Group I (Main) had further decrease in the severity of dyspnea, by $95.2 \%$ in the mMRC scale $(2.1 \pm 0.3$ points before the treatment, $-0.1 \pm 0.04$ points, $p=0.0011$ after the treatment) (Table 1$)$; by $85 \%$ in the Borg scale $(3.2 \pm 0.4$ points before the treatment; $0.45 \pm 0.2$ points, $\mathrm{p}=0.0018$ after the treatment) (Table 2).

When assessing the quality of life according to EQ-5D questionnaire, further positive dynamics was noted - an improvement in the quality of life by $30.9 \%$ (11.3 \pm 0.3 points before the treatment, 7.8 \pm 0.1 points; $p=0.01$ after the treatment).

Evaluation of chest excursion, lung capacity, quality of life according to the EQ-5D questionnaire demonstrated less pronounced positive dynamics of the indicators in Group (Control).

The results of X-ray computed tomography performed at the final stage in patients with residual pathological radiological abnormalities at the time of inclusion in the study demonstrated more reliable positive dynamics in Group I (Main). Control computed to- mography of lungs of the patients in Group I (Main) demonstrated that 95 out of 96 patients (98.9\%) who initially had residual pathological abnormalities on the RCT scan did not have any pathological abnormalities in the lungs (CT-0); 1 of 96 patients (1.1\%) had a single residual pathological abnormality of mild degree (CT-1) of the "ground glass" type with reticular striation $(p=0.002)$. In Group II (Control), 85 out of 96 patients (88.5\%) did not have any pathological changes in lungs (CT-0) and 11 of 96 patients $(11.5 \%)$ had similar single residual mild pathological abnormalities (CT -1 , $\mathrm{p}=0.01$ ).

\section{Conclusion}

The results of the clinical study demonstrated that assessment of effectiveness of the low-frequency magnetic therapy in the complex medical rehabilitation of patients with pneumonia caused by the new coronavirus infection contributes to improvement of clinical and laboratory parameters, respiratory function of the patients. This is confirmed by laboratory test data, subjective dynamics of patient complaints, physical examination, spirometry data, and a decrease in severity of dyspnea by the Borg scale and the mMRC dyspnea scale. A significant reduction in duration of the rehabilitation period and terms of incapacity for work, regression of residual infiltrative changes in lungs after pneumonia with confirmation of dynamic changes according to X-ray computed tomography have been revealed.

When assessing the effectiveness of low-frequency magnetic therapy in the complex medical rehabilitation of the patients who have suffered pneumonia caused by the new coronavirus infection, an improvement in the general well-being of patients, psychoemotional state has been revealed. As well as restoring activity in everyday life and improving the quality of life of the patients.

Absence of any adverse events during the study, associated with use of low-frequency magnetic therapy, good tolerance of magnetic therapy procedures by all patients of Group I (Main Group) (100 persons) allow us to conclude that inclusion of the low-frequency magnetic therapy in the complex medical rehabilitation of the patients who have undergone pneumonia caused by the new coronavirus infection, is safe and does not entail a risk of adverse events for the patients.

The authors declare no conflicts of interest. 
Bibliography

1. Zhu N., et al. "New coronavirus from patients with pneumonia in China, 2019". The New England Journal of Medicine 382.8 (2020): 727-733.

2. Dong Y., et al. "Epidemiological characteristics of 2143 pediatric patients with 2019 coronavirus disease in china". Pediatrics 146.5 (2020).

3. WHO. "Coronavirus disease (COVID-19) pandemic". Geneva: WHO (2020).

4. "The Epidemiological Characteristics of an Outbreak of 2019 New Coronavirus Diseases (COVID-19) - China, 2020". China CDC Weekly 2.8 (2020): 113-122.

5. Huang Y., et al. "CoVDB: a comprehensive database for comparative analysis of coronavirus genes and genomes". Nucleic Acids Research 36 (2008): D504-D511.

6. Li J., et al. "Association of renin-angiotensin system inhibitors with severity or risk of death in patients with hypertension hospitalized for Coronavirus disease 2019 (COVID-19) infection in Wuhan, China". JAMA Cardiology (2020): e201624.

7. Mehra MR., et al. "Cardiovascular Disease, Drug Therapy and Mortality in Covid-19". The New England Journal of Medicine 382 (2020): e102.

8. Huang C., et al. "Clinical features of patients infected with 2019 new coronavirus in Wuhan, China”. Lancet 395.10223 (2020): 497-506.

9. "Temporary Clinical recommendations for medical rehabilitation for a new coronavirus infection". Version 2.0. dated July 31, 2020 (2020).

10. Bodrova RA., et al. "Efficacy of low frequency magnetotherapy in the patients recovering from pneumonia caused by COVID-19". Problems of Balneology, Physiotherapy and Medical Physical Culture 97.6 (2020): 11-16.

11. https://zdrav.expert/index.php/\%D0\%A1\%D1\%82\%D0\%B 0\%D1\%82\%D1\%8C\%D1\%8F:\%D0\%9A\%D0\%BE\%D1\%80 \%D0\%BE\%D0\%BD\%D0\%B0\%D0\%B2\%D0\%B8\%D1\%80\% D1\%83\%D1\%81_COVID-19

12. Al-Aly Z., et al. "High-dimensional characterization of postacute sequalae of COVID-19”. Nature (2021).
Volume 5 Issue 10 October 2021

C) All rights are reserved by RA Bodrova., et al. 